\title{
Determinants of condom use by men in extramarital relationships in Nigeria
}

This article was published in the following Dove Press journal:

HIVIAIDS - Research and Palliative Care

23 May 2013

Number of times this article has been viewed

\author{
Augustine Ankomah' \\ Samson B Adebayo ${ }^{2,3}$ \\ Jennifer Anyanti ${ }^{3}$ \\ Olaronke Ladipo $3, \dagger$ \\ Bright Ekweremadu ${ }^{3}$ \\ 'Department of Population, Family \\ and Reproductive Health, School \\ of Public Health, University of \\ Ghana, Accra, Ghana; ${ }^{2}$ Directorate \\ of Planning, Research and Statistics, \\ National Agency for the Control \\ of Food and Drugs Administration \\ and Control, Abuja, Nigeria; ${ }^{3}$ Society \\ for Family Health, Abuja, Nigeria \\ †Olaronke Ladipo passed away on \\ $30 / 10 / 2012$
}

Background: Extramarital sex is a high-risk behavior in terms of Human Immunodeficiency Virus (HIV) transmission, yet condom use in extramarital relationships is an understudied area in Africa, and Nigeria in particular, where such liaisons are not uncommon. This study highlights key determinants of condom use among men who engage in extramarital sex in Nigeria.

Methods: Results are based on a subsample of 642 married men from a combined dataset from three waves of the National HIV/AIDS and Reproductive Health Survey (NARHS), a set of multiround nationally representative surveys. Logistic regression was employed to explore possible determinants of condom use in extramarital sex. The motivation, opportunity, and ability model was applied in selecting the determinants.

Results: HIV risk-reduction knowledge was found not to be associated with condom use. At the full logistic regression model, being of the Yoruba tribe, having no misconception about HIV transmission, ability to discuss condom use, and ability to wear condoms were the key variables significantly associated with condom use in extramarital sex.

Conclusion: Implementing HIV risk-reduction behavior change requires more than knowledge. Behavioral skills in condom use are critical. Intervention efforts should move away from knowledge about risk to concentrate on improving skills on how to discuss condom use and wear condoms correctly.

Keywords: married men, extramarital sex, condom use, motivation, opportunity, Nigeria

\section{Introduction}

By the end of 2005, Nigeria was adjudged to have the third-highest burden of HIV in the world after South Africa and India. ${ }^{1}$ About 3.5-4.0 million Nigerians are currently infected with the virus, ${ }^{2}$ with over 1 million orphans currently in the country. Nigeria, with a population of about 162 million people, has an estimated adult HIV prevalence of $3.6 \%$ according to the findings from a 2007 population-based household survey. ${ }^{3}$ Nigeria still has a generalized epidemic, with infection rates in some high-risk groups being as high as 31\%. ${ }^{4}$ Various programs aimed at reducing transmission of HIV and mitigating the impact of HIV and AIDS have been embarked upon in order to ensure that Nigeria accomplishes the United Nations' Millennium Development Goals and halts the spread of HIV.

Since the first case of an HIV epidemic in Nigeria over two decades ago, Nigerian government and multilateral organizations and partners have committed substantial political, human, and financial resources to stem the tide of the infection. This was initially through a monosector approach, but more recently through multisector
Correspondence: Augustine Ankoma Department of Population, Family and Reproductive Health, School of Public Health, University of Ghana, Legon, Accra, Ghana Tel +23326I 524407

Email aankomah@ug.edu.gh 
response programs aimed at preventing the spread of the virus and mitigating its impact on the populace. From the results of the 2005 Sero-prevalence Sentinel Survey in Nigeria, ${ }^{2}$ a total of 2.86 million people were estimated to be living with the virus. The survey estimated new infections to be at 296,320 (adults) and 73,550 (children under 15 years). Condom use is receiving greater attention today because of its usefulness as a prophylactic against sexually transmitted infection (STIs) and HIVs among sexually active people.

Globally, surveys have reported the practice of extramarital sexual activities among both married men and women. ${ }^{5}$ In Nigeria, where culturally men are permitted to have more than one wife, extramarital sex by men, though not encouraged, is tolerable. Survey data among men in predominantly male and "mobile" occupations have supported the pervasiveness of extramarital sex in Nigeria. A study by Aniebue and Aniebue ${ }^{6}$ among transport workers showed that as high as 79\% reported having engaged in extramarital sex in the past. In another study among soldiers in army barracks in Kwara State, Nigeria, $46 \%$ had engaged in extramarital sex. In another study among policemen in Akure, Ondo State, $61 \%$ of married respondents reported having extramarital partners. ${ }^{7}$ But extramarital sex is not limited to mobile and itinerant husbands and most-at-risk populations alone. Analysis of the 2003 Nigeria Demographic and Health Survey showed that $11 \%$ of married men reported having had extramarital sex. ${ }^{8}$ Several studies document the existence of extramarital liaisons in western Nigeria. ${ }^{9-12}$ In his study on extramarital sexual behavior in Nigeria, IsiugoAbanihe ${ }^{13}$ examined HIV/AIDS awareness and perceptions as related to some socioeconomic factors in five towns. Although extramarital sexual relationships are more common among men compared to women, the practice exists within both groups, and there also exist concurrent sexual partnerships and assorted sexual mixing between higher-risk persons and persons at lower risk of HIV infection. ${ }^{14}$

In a recent study, ${ }^{15}$ it was observed that a reasonable proportion of Nigerians are exposed to HIV infection through extramarital sex, yet little is known about the level and determinants of condom use in extramarital sex in Nigeria or sub-Saharan Africa as a whole. One of the few published studies in Africa was in Benin, where it was reported that condom use is low in extramarital relationships. ${ }^{16}$ Most studies on condom use in sexual relationships concentrate on either premarital or marital relationships without isolating whether the relationships are extramarital, even though the practice of extramarital sex is fairly common in Nigeria, and can be considered a high-risk behavior. In a country with a fairly high HIV prevalence rate, marriage by itself may be a risk factor for infection. ${ }^{17}$ It is reported that a substantial proportion of HIV infections among men in Kenya and Zambia may be acquired outside of marriage. ${ }^{17}$ Condom use in extramarital relationships is understudied mainly because large-scale surveys with large sample sizes are needed to obtain adequate data for meaningful analysis, and few such studies are available in Africa. Until recently, the multicountry, multiround demographic and health surveys, now coordinated by ICF Macro (formerly ORC Macro), did not include men as a key sample of interest. This paper addresses the issue of sample size by combining data from three rounds of the National HIV/AIDS and Reproductive Health Survey (NARHS) conducted by the Federal Ministry of Health, Nigeria.

To ensure that the research findings were relevant to the development of condom-promotion interventions, we employed Rothschild's ${ }^{18}$ conceptual social marketing motivation, opportunity, and ability (MOA) model designed to identify behavior determinants mutable to change by social marketing interventions. Given that about $80 \%$ of condoms in Nigeria are socially marketed, we considered this a useful framework. Motivation, opportunity, and ability to "behave" have been theorized as being the summary determinants of behavior change that health-promotion interventions are, to varying degrees, capable of influencing. ${ }^{18-21}$ Specifically defined, motivation is an individual's arousal or desire to perform a promoted behavior; opportunity refers to institutional or structural factors that influence an individual's chance to perform a promoted behavior. ${ }^{20}$ Ability is an individual's skills or proficiencies needed to perform a promoted behavior. The framework, as shown in Figure 1, does approach behavior change along three key lines. Does the target group have the opportunity to engage in the desired behavior? Does the target group have the motivation to engage in the desired behavior? Does the target group have the ability to engage in the desired behavior? These three summary constructs proximally explain a person's use of preventive or curative health products and services and/or risk-reducing behavior. ${ }^{19-24}$ In other words, opportunity, ability, and motivation facilitate or inhibit the behavior, and they can be enhanced, increased, or positively changed within the target audience by the intervention agency. ${ }^{25,26}$ The MOA framework has been applied in several behavior-change contexts. These include the design, implementation, and evaluation of a social marketing intervention in Burundi ${ }^{27}$ and safer-sex interventions in Laos. ${ }^{28}$ Outside of behavior change in public health, the framework has been used to explain knowledge-sharing experience. ${ }^{29}$

This paper seeks to answer the broad question of how the MOA framework can be used in explaining condom use by examining the motivation, opportunity, and ability factors that affect condom use in extramarital sexual relationships. 


\begin{tabular}{|c|c|}
\hline Variables & Definitions \\
\hline Motivation & This is an individual's desire to perform a promoted behavior. \\
\hline Self assessment & $\begin{array}{l}\text { This was measured based on respondent's attitude to contracting HIV. } \\
\text { Respondents were asked if they were at high risk of contracting HIV (coded ' } 1 \text { ') } \\
\text { for affirmative and (coded ' } 0 \text { ') otherwise. }\end{array}$ \\
\hline Efficacy & $\begin{array}{l}\text { This was also measured on whether a respondent perceived condom to be effective } \\
\text { against HIV transmission (coded as ' '1') or not (coded as '0'). }\end{array}$ \\
\hline $\begin{array}{l}\text { Beliefs/Misconceptions } \\
\text { about HIV transmission }\end{array}$ & $\begin{array}{l}\text { This was measured based on the respondents' perception to whether wearing three } \\
\text { condoms at the same time provides more protection against HIV than one condom, } \\
\text { (coded as ' } 1 \text { ') if they say no and (coded as ' } 0 \text { ') otherwise. }\end{array}$ \\
\hline Opportunity & $\begin{array}{l}\text { This refers to institutional or structural factors that influence an individual's } \\
\text { chance to perform a promoted behavior. }\end{array}$ \\
\hline Affordability & $\begin{array}{l}\text { This was measured based on whether a respondent perceived condoms to be } \\
\text { affordable (coded as ' } 1 \text { ') or not (coded as ' } 0 \text { ') }\end{array}$ \\
\hline Availability & $\begin{array}{l}\text { This was measured based on frequency and accessibility to condom. Respondents } \\
\text { were asked if condoms are available within } 1 / 2 \text { kilometer from their houses. This } \\
\text { was coded as ' } 1 \text { ' if respondents answered to the affirmative while ' } 0 \text { ' if otherwise. }\end{array}$ \\
\hline Self efficacy (condom use) & $\begin{array}{l}\text { This was considered as a self-efficacy indicator for wearing a condom. Questions } \\
\text { on how confident a respondent is in his ability to wear a condom was used for } \\
\text { measuring this. Respondents who were confident in their abilities to use condoms } \\
\text { were coded } 1 \text {, and } 10 \text { if not confident at all. }\end{array}$ \\
\hline Ability variables & $\begin{array}{l}\text { This is an individual's skills or proficiencies needed to perform a promoted } \\
\text { behavior. }\end{array}$ \\
\hline $\begin{array}{l}\text { Knowledge (AIDS related } \\
\text { death) }\end{array}$ & $\begin{array}{l}\text { Respondents were asked whether they know someone who died of AIDS. This was } \\
\text { (coded as ' } 1 \text { ') if respondents answer that they know someone and (coded as ' } 0 \text { ') } \\
\text { otherwise. }\end{array}$ \\
\hline $\begin{array}{l}\text { Knowledge (AIDS has no } \\
\text { cure) }\end{array}$ & $\begin{array}{l}\text { Respondents were asked whether they know if AIDS has a cure or not. } \\
\text { This was coded as ' } 1 \text { ' if respondents answered that AIDS does not have a cure; } \\
\text { and '0' otherwise. }\end{array}$ \\
\hline $\begin{array}{l}\text { Knowledge (Healthy } \\
\text { looking HIV carriers) }\end{array}$ & $\begin{array}{l}\text { In the surveys, a question on whether respondents know that a healthy looking } \\
\text { person could be HIV positive was included in the questionnaire. Respondents who } \\
\text { knew that a healthy looking person can be HIV positive were coded " } 1 \text { ' while those } \\
\text { who did not know were coded as " } 0 \text { ". }\end{array}$ \\
\hline $\begin{array}{l}\text { Knowledge (Modes of } \\
\text { prevention) }\end{array}$ & $\begin{array}{l}\text { Staying with one uninfected partner and using condoms correctly and } \\
\text { consistently was considered as having correct knowledge of mode of } \\
\text { prevention (UNAIDS indicator). A respondent who answered in affirmative to all } \\
\text { these questions were coded as ' } 1 \text { ' and '0' otherwise. }\end{array}$ \\
\hline $\begin{array}{l}\text { Knowledge of HIV } \\
\text { transmission routes }\end{array}$ & $\begin{array}{l}\text { Measured on the respondent's knowledge about modes/routes of HIV transmission. } \\
\text { Coded as ' } 1 \text { ' if respondent identifies that the correct modes of transmission of HIV } \\
\text { are through sexual intercourse, sharing of razors, sharing of sharp objects, use of } \\
\text { unsterilized needles, or coded as ' } 0 \text { ' if otherwise. }\end{array}$ \\
\hline
\end{tabular}

Figure I Motivation, opportunity, and ability variables.

Abbreviations: AIDs, acquired immunodeficiency syndrome; HIV, Human Immunodeficiency Virus infection.

It further seeks to assess the relative strengths of each of the three groups of variables in determining condom use in last extramarital sex.

\section{Methods and materials}

The data upon which this study is based were derived from a combination of three datasets from three consecutive multiround cross-sectional surveys (2003, 2005, 2007) conducted by the Nigeria Federal Ministry of Health among women (15-49 years old) and men (15-64 years old). ${ }^{30,31}$ The total sample sizes of the three surveys were 10,090 in 2003, 10,081 in 2005, and 11,521 in 2007. Of these figures, only 4962 males in 2003, 5396 males in 2005, and 6161 males in 2007 were sampled. Further, only 2569 male respondents in 
2003, another 2661 male respondents in 2005, and 3009 male respondents in 2007 were married. Of the male respondents in a stable relationship, only 202 in 2003, 211 in 2005, and 229 in 2007 had had extramarital sex in the last 12 months. Altogether, 642 married or cohabiting men reported having had extramarital sex in the past 12 months. This forms the sample for this paper. The multiround cross-sectional NARHS employed the same methodology and were all conducted across all the 36 states and the Federal Capital Territory in Nigeria. This paper is based on data from a subsample of 642 married men who reported extramarital sex within 12 months of the survey. This represented $8.3 \%$ of all married men in the total sample.

Probability sampling was employed to select the eligible respondents: males age 15-64 years and females age 15-49 years. The first level included a selection of rural and urban localities. Localities were classified into rural and urban, with settlements less than 20,000 inhabitants classified as rural. Localities were then grouped in geographic order according to size. The first three big towns in a state were grouped as a stratum and called major towns; all other urban settlements were grouped to form another stratum and called medium towns. The third stratum included all rural localities in the state. One major town, one medium town, and three rural localities were selected from each of the strata, with probability proportional to size. The second stage involved selection of enumeration areas using the National Population Commission updated sampling frame. The third stage involved the selection of individual respondents according to the age-eligibility criterion. Probability sampling was employed to select respondents at the individual level. The sample was later weighted to reflect the actual size of the population of each state.

\section{Data analysis}

For the purpose of this paper, a database was created of all male respondents in stable relationships (defined as currently married or cohabiting with a sexual partner) who reported having had extramarital sex, yielding a total of 642 respondents. Demographic characteristics about the respondents that were available in the data and used for analysis in this paper include educational attainment, religion, locality (rural/urban), age, and whether respondent had been away from home for more than a month in the last 12 months preceding the survey.

\section{Dependent variable}

The dependent variable for this study was condom use in the last extramarital sex act. Of all the respondents that were in stable relationships who had had nonspousal sex within the last 12 months before the survey, a question on whether the respondents used a condom during the last extramarital sex act was asked. Suppose the dependent variable is $y$, which takes a value of 1 if a respondent used a condom during the last nonmarital sex act, and 0 otherwise (ie, if a condom was not used).

\section{Independent variables}

A number of independent variables were used.

\section{Age of the respondents}

Current age of the respondent was measured in years, and this ranged between 15 and 64 years for males. Age was included as a categorized variable in all models.

\section{Place (locality) of residence}

Place of residence was measured as to whether the respondent resided in an urban or rural area at the time of the survey. This was coded as 1 if the respondent resided in an urban area, and 0 if they resided in a rural area.

\section{Educational attainment}

This is a variable that identifies the highest level of education a respondent had attained at the time of the survey. Two dummy variables were created for this variable, ie, secondary/ higher and Koranic/primary (secondary/higher 1, never attended any formal school 0 ; Koranic/primary 1 , never attended formal school 0 ).

\section{Religion}

Given the impact religion plays in condom use, this was also included in this study. Dummy variables were created for Islam and Christianity separately, with traditional and other religions as the reference category.

\section{Geographical zones}

For this paper, we dichotomized Nigeria into two geographical parts: north $=0$ and south $=1$.

\section{Ethnicity}

Nigeria is a multiethnic nation. Dummies were created for the three major ethnic groups: Hausa, Igbo, and Yoruba (with others considered as the reference category). Based on the MOA framework, independent variables were developed, as shown earlier in Figure 1.

In order to explore any existing relationship between the outcome variable of interest and some selected determinants, 
a binary variable that identifies whether a condom was used (or not used) in the last extramarital sex was created as the outcome (dependent) variable, as described earlier. ${ }^{32}$ At the multivariate level, multiple logistic regression was fitted using Stata version 9.2 SE (StataCorp LP, College Station, TX, USA). ${ }^{33}$

Both bivariate and multivariate analyses were carried out. At the bivariate level, the effect of each individual determinant was cross-classified with the dependent variable and its significance assessed based on Pearson's Chi-squared test. ${ }^{32}$ In the multivariate analyses, an attempt was made to explore the influence of MOA separately and jointly in the presence of the background characteristics of the respondents. To achieve this, independent variables were grouped according to the MOA framework into the following models:

- $\mathrm{M}_{1}$ : condom use = year of study

- $\mathrm{M}_{1}$ : demographic variables

- $\mathrm{M}_{2}$ : demographic variables + motivation variables

- $\mathrm{M}_{3}$ : demographic variables + motivation variables + opportunity

- $\mathrm{M}_{4}$ : demographic variables + opportunity variables

- $\mathrm{M}_{5}$ : demographic variables + ability variables

- $\mathrm{M}_{6}$ : demographic variables + motivation variables + opportunity + ability

In the preliminary analyses, several models were explored, but discussion shall be based only on models $M_{1}$, $\mathrm{M}_{2}, \mathrm{M}_{3}$ and $\mathrm{M}_{6}$. As a preceding step to selecting our models, logistic regression models were fitted in a systematic order by controlling for different sets of covariates so as to identify the set of determinants to be controlled for in the final model. Firstly, in model $\mathrm{M}_{1}$, we fitted a logistic regression model of the dependent variable on only background variables. Subsequently, we controlled for different groups of independent variables, as described for models $M_{2}, M_{3}$, and $\mathrm{M}_{6}$.

\section{Results}

This paper highlights some determinants of condom use in last extramarital sex among 642 married or cohabiting men in Nigeria between 2003 and 2007.

\section{Descriptive analysis}

The study is limited to married or cohabiting men who reported that they had engaged in extramarital sex 12 months prior to the survey $(\mathrm{n}=642)$. Out of the 7070 married/ cohabiting men in the surveys, 642 , representing $8.3 \%$, had had extramarital sex in the 12 months preceding the survey. This seems to be consistent with other national surveys, which reported $11 \%$ of men in unions engaging in extramarital sex within the last 12 months. ${ }^{8}$ The summary descriptive information on some demographic characteristics of the 642 respondents is presented in Table 1. The mean age of respondents who engaged in extramarital sex was 35.0 years (standard deviation 9.5 years). Extramarital sex was more prevalent among respondents aged 35-49 years $(40.7 \%)$. A higher proportion of respondents who engaged in extramarital sex had at least secondary-level

Table I Demographic characteristics of men who engage in extramarital relationships

\begin{tabular}{|c|c|c|}
\hline Variables & $\begin{array}{l}\text { Frequency } \\
n=642\end{array}$ & Percentage \\
\hline \multicolumn{3}{|l|}{ Age of respondents (years) } \\
\hline $15-19$ & 16 & 2.5 \\
\hline $20-24$ & 59 & 9.2 \\
\hline $25-34$ & 254 & 39.6 \\
\hline $35-49$ & 261 & 40.7 \\
\hline $50-64$ & 52 & 8.1 \\
\hline \multicolumn{3}{|c|}{ Condom use during last extramarital sex } \\
\hline Did not use condom & 345 & 53.7 \\
\hline Used condom & 297 & 46.3 \\
\hline \multicolumn{3}{|l|}{ Education level } \\
\hline No formal education & 52 & 8.1 \\
\hline Primary & 203 & 31.6 \\
\hline Secondary and higher & 387 & 60.3 \\
\hline \multicolumn{3}{|l|}{ Religion } \\
\hline Islam & 191 & 29.8 \\
\hline Christianity & 424 & 66.0 \\
\hline Traditional/others & 27 & 4.2 \\
\hline \multicolumn{3}{|l|}{ Ethnicity } \\
\hline Hausa & 46 & 7.2 \\
\hline Igbo & 62 & 9.7 \\
\hline Yoruba & 191 & 29.8 \\
\hline Others & 343 & 53.4 \\
\hline \multicolumn{3}{|l|}{ Residence } \\
\hline Rural & 398 & 62.0 \\
\hline Urban & 244 & 38.0 \\
\hline \multicolumn{3}{|l|}{ Multiple nonspousal sex } \\
\hline No & 317 & 58.4 \\
\hline Yes: have sex with nonspouse & 325 & 41.6 \\
\hline \multicolumn{3}{|l|}{ Sex in exchange for gift } \\
\hline Never had sex for gift & 479 & 74.6 \\
\hline Have had sex for gift & 163 & 25.4 \\
\hline \multicolumn{3}{|l|}{ Alcohol consumption } \\
\hline Every day & 89 & 13.9 \\
\hline Once a week or less & 267 & 41.6 \\
\hline Others & 286 & 44.5 \\
\hline \multicolumn{3}{|c|}{ Away from home for more than $I$ month in the last 12 months } \\
\hline No & 370 & 57.6 \\
\hline Yes & 272 & 42.4 \\
\hline \multicolumn{3}{|c|}{ Do you agree or disagree that condoms are easy to obtain? } \\
\hline Disagree & 123 & 19.2 \\
\hline Agree & 519 & 80.8 \\
\hline
\end{tabular}


education $(60.3 \%)$ compared with only $31.6 \%$ of those who had primary education only. Three out of ten men who engaged in extramarital sex were of the Yoruba tribe of southwest Nigeria. Over $60 \%$ of men who engaged in extramarital sex lived in rural areas, and in terms of religion, two-thirds were Christians. Some of the respondents reported having had sex with multiple extramarital partners. Of the 642 who had had extramarital sex, $41.6 \%$ had multiple extramarital partners. Although a high proportion felt condoms were affordable $(83.5 \%)$, and easy to obtain $(80.8 \%)$, less than one-half $(46.3 \%)$ of the sample used condoms in their last extramarital sex. On knowledge about HIV, 69\% had knowledge about all five modes of transmission of HIV.

\section{Bivariate analysis}

Tests of differences of proportions for some determinants of condom use in extramarital sex were carried out using Pearson's Chi-squared test of association or Fisher's exact test for $2 \times 2$ contingency tables. ${ }^{32}$ Table 2 presents the percentages of condom use in extramarital sex according to some relevant determinants of condom use. Overall, only $46.3 \%$ of married men who engaged in extramarital sex used a condom during their last extramarital sex. Regarding respondents' demographic characteristics, it was found at the bivariate level that condom use in extramarital sex was not statistically associated with age or religion. However, it was statistically associated with education $(P<0.0001)$, and rural/urban residence $(P<0.0001)$, with only $39.4 \%$ in rural areas compared with $57.4 \%$ in urban areas $(P<0.0001)$ using condoms in the last extramarital sex. There was also a positive relationship between education and condom use. While only $23.1 \%$ of respondents with no formal education and $36.9 \%$ of those with below secondary education used condoms, the figure for those with at least secondary level of education was $54.3 \%$ ( $P<0.0001)$. In terms of ethnic origins, Yoruba and Igbo married men who engaged in extramarital sex were more likely to use condoms compared with their Hausa counterparts $(P<0.05)$.

We also explored at the bivariate level relationships between each of the MOA indicators and condom use. On motivation indicators, there was no relationship between personal risk perception and condom use. The two opportunity indicators were strongly associated with condom use. Men who agreed that condoms were easily available or were easy to obtain were more likely to use condoms. Over one-half $(53.2 \%)$ of men who agreed that condoms were affordable compared with only $11.3 \%$ who disagreed were more likely to have used condoms in the last extramarital sex $(P<0.0001)$. Married men who were not embarrassed to buy condoms were more likely to use condoms in extramarital $\operatorname{sex}(P<0.0001)$.

Several of the ability indicators were statistically related to condom use at the $P<0.0001$ level. These included knowledge that a healthy-looking person can be HIVpositive, knowledge that condoms protect against STI/ HIV and unwanted pregnancy, and knowledge about HIV (as measured by UNAIDS). Having known someone who died of AIDS was found not to be related to condom use, but the knowledge that AIDS has no cure had a significant association with condom use $(P<0.05)$. Similarly, while $60.7 \%$ of men who felt they could convince their sexual partners to use condoms actually did use condoms in extramarital sex, compared with only $9.9 \%$ of those who said they could not convince their partners. Married men who were able to discuss condom use were more likely to use condoms in extramarital sex $(P<0.0001)$. Also associated with condom use were aspects of ability, which borders on skills and self-efficacy.

\section{Multivariate analysis}

Findings from multiple logistic regression for models $M_{1}$, $\mathrm{M}_{2}, \mathrm{M}_{3}$ and $\mathrm{M}_{6}$ are presented in Table 3. Results for Model $M_{1}$ presented in Table 3 show that adjusting for other background characteristics significantly reversed the pattern of association between condom use in extramarital sex and educational attainment $(P<0.05)$. Being a Yoruba or living in an urban area was significantly associated with condom use in extramarital sex. Men who were of the Yoruba tribe were about 1.54 times more likely to use condoms (odds ratio [OR] $1.54, P=0.039$ ) than those from other tribes, and respondents living in urban areas were $74 \%$ more likely to use condoms in extramarital sex than those living in rural areas. In addition to the background factors, the predictive power of the motivation, opportunity, and ability factors are presented for models $\mathrm{M}_{2}, \mathrm{M}_{3}$ and $\mathrm{M}_{6}$ in Table 3. The direction of significance for demographic characteristics in models $\mathrm{M}_{2}$ and $\mathrm{M}_{3}$ were similar; therefore, we restrict the discussion to the results of MOA indicators alone in those two models. In model $\mathrm{M}_{2}$, the belief that condoms protect against STI/HIV and unwanted pregnancies, not being embarrassed about buying condoms in public, and not having misconceptions about mode of transmission of HIV were significantly related to condom use in extramarital sex. Respondents who believed that condoms protect against 
Table 2 Bivariate analysis of condom use in extramarital sex

\begin{tabular}{|c|c|c|c|c|}
\hline & \multicolumn{2}{|c|}{ Condom use in extramarital sex (\%) } & \multirow[t]{2}{*}{ Total } & \multirow{2}{*}{$\begin{array}{l}P \text {-value } \\
\text { from } \chi^{2}\end{array}$} \\
\hline & Used condom & Did not use & & \\
\hline \multicolumn{5}{|l|}{ Variables } \\
\hline Respondents' age (years) & & & & 0.187 \\
\hline $15-19$ & 56.3 & 43.7 & 16 & \\
\hline $20-24$ & 45.8 & 54.2 & 59 & \\
\hline $25-34$ & 48.4 & 51.6 & 254 & \\
\hline $35-49$ & 46.7 & 53.3 & 261 & \\
\hline $50-64$ & 30.8 & 69.2 & 52 & \\
\hline Education & & & & $<0.000$ I \\
\hline No formal education & 23.1 & 76.9 & 52 & \\
\hline Below secondary & 36.9 & 63.1 & 203 & \\
\hline Secondary and higher & 54.3 & 45.7 & 387 & \\
\hline Locality & & & & $<0.0001$ \\
\hline Rural & 39.4 & 60.6 & 398 & \\
\hline Urban & 57.4 & 42.6 & 244 & \\
\hline Religion & & & & 0.813 \\
\hline Islam & 44.5 & 55.5 & 191 & \\
\hline Christian (Catholic and Protestant) & 47.2 & 52.8 & 424 & \\
\hline Others & 44.4 & 55.6 & 27 & \\
\hline Ethnicity & & & & 0.030 \\
\hline Hausa & 39.1 & 60.9 & 46 & \\
\hline lgbo & 46.8 & 53.2 & 62 & \\
\hline Yoruba & 55.0 & 45.0 & 191 & \\
\hline Others & 42.3 & 57.7 & 343 & \\
\hline Alcohol intake & & & & 0.484 \\
\hline Every day & 43.8 & 56.2 & 89 & \\
\hline Sometimes & 49.1 & 50.9 & 267 & \\
\hline Never & 44.4 & 55.6 & 286 & \\
\hline Away from home for more than I month & & & & 0.037 \\
\hline \multicolumn{5}{|l|}{ in the last 12 months } \\
\hline Yes & 42.7 & 57.3 & 370 & \\
\hline No & 51.1 & 48.9 & 272 & \\
\hline \multicolumn{5}{|l|}{ Motivation variables } \\
\hline Self-assessment/appraisal of contracting HIV & & & & 0.513 \\
\hline High risk & 41.0 & 59.0 & 39 & \\
\hline Others & 46.6 & 53.4 & 603 & \\
\hline Condom protects against STI/HIV and & & & & $<0.0001$ \\
\hline \multicolumn{5}{|l|}{ prevents unwanted pregnancy } \\
\hline Agreed & 51.2 & 48.8 & 541 & \\
\hline Disagreed & 19.8 & 80.2 & 101 & \\
\hline Are you embarrassed to buy condoms? & & & & $<0.0001$ \\
\hline Not embarrassed & 52.1 & 47.9 & 401 & \\
\hline Embarrassed & 36.5 & 63.5 & 241 & \\
\hline Misconception about HIV transmission & & & & 0.004 \\
\hline Yes & 40.8 & 59.2 & 338 & \\
\hline No & 52.3 & 47.7 & 304 & \\
\hline \multicolumn{5}{|l|}{ Opportunity variables } \\
\hline Condom affordability & & & & $<0.000$ I \\
\hline Agreed & 53.2 & 46.8 & 536 & \\
\hline Disagreed & 11.3 & 88.7 & 106 & \\
\hline Condoms easy to obtain & & & & $<0.000$ I \\
\hline Agreed & 52.6 & 47.4 & 519 & \\
\hline Disagreed & 19.5 & 80.5 & 123 & \\
\hline Know how to wear a condom? & & & & $<0.000$ I \\
\hline Yes & 62.7 & 37.3 & 445 & \\
\hline No & 9.1 & 90.9 & 197 & \\
\hline
\end{tabular}


Table 2 (Continued)

\begin{tabular}{|c|c|c|c|c|}
\hline & \multicolumn{2}{|c|}{ Condom use in extramarital sex (\%) } & \multirow[t]{2}{*}{ Total } & \multirow{2}{*}{$\begin{array}{l}P \text {-value } \\
\text { from } \chi^{2}\end{array}$} \\
\hline & Used condom & $\overline{\text { Did not use }}$ & & \\
\hline \multicolumn{5}{|l|}{ Ability variables } \\
\hline Know someone who died of AIDS & & & & 0.108 \\
\hline Yes & 51.7 & 48.3 & 172 & \\
\hline No & 44.3 & 55.7 & 470 & \\
\hline Know that AIDS has no cure & & & & 0.012 \\
\hline Yes & 48.6 & 51.4 & 529 & \\
\hline No & 35.4 & 64.6 & 113 & \\
\hline Know that healthy-looking persons can be & & & & $<0.0001$ \\
\hline \multicolumn{5}{|l|}{ HIV-positive } \\
\hline Yes & 50.8 & 49.2 & 510 & \\
\hline No & 28.8 & 71.2 & 132 & \\
\hline \multicolumn{5}{|l|}{ UNAIDS } \\
\hline Condom use and remain with one & & & & $<0.000$ I \\
\hline \multicolumn{5}{|l|}{ uninfected partner } \\
\hline Yes & 51.9 & 48.1 & 503 & \\
\hline No & 25.9 & 74.1 & 139 & \\
\hline Discussed condom with partner? & & & & $<0.0001$ \\
\hline Yes & 69.0 & 31.0 & 381 & \\
\hline No & 13.0 & 87.0 & 261 & \\
\hline Can convince partner to use condom? & & & & $<0.0001$ \\
\hline Yes & 60.7 & 39.3 & 460 & \\
\hline No & 9.9 & 90.1 & 182 & \\
\hline
\end{tabular}

Abbreviations: AIDS, acquired immunodeficiency syndrome; HIV, Human Immunodeficiency Virus infection; STI, sexually transmitted infection.

STI/HIV and unwanted pregnancy were about four times more likely to use condoms in extramarital sex compared with their counterparts who did not believe (OR 4.181, $P<0.0001)$. Further, those who said that they would not be embarrassed to buy condoms were 1.53 times more likely to use a condom in such a sexual relationship than their counterparts who would be embarrassed to buy condoms (OR 1.53, $P=0.022$ ). Having misconceptions about mode of transmission of HIV was negatively associated with condom use in extramarital sex. Respondents who had some misconceptions were 0.57 times less likely to use condoms in extramarital sex than their counterparts who did not have any misconception.

Turning to model $\mathrm{M}_{3}$, the direction of significance for the motivation variables were similar to model $\mathrm{M}_{2}$, except for being embarrassed to buy a condom, which was not significant. Again, the likelihood was halved for belief that condoms protect against STI/HIV and unwanted pregnancies. Therefore, we shall concentrate on discussing the results of the opportunity variables. Respondents who knew or believed that condoms were easy to obtain were 3.47 times more likely to use condoms compared with their counterparts who did not know that condoms were easy to obtain (OR 3.473, $P=0.003$ ). Knowledge of how to wear a condom was positively and significantly associated with condom use in extramarital sex. Those who knew how to wear condoms were 13 times more likely to use a condom than their counterparts who did not know how to wear them (OR 13.483, $P<0.0001$ ). In model $\mathrm{M}_{6}$, the results for the motivation and opportunity variables were similar to model $\mathrm{M}_{3}$. Therefore, we present the results for the only significant ability variable. Of all the ability variables, only ability to discuss condom use with one's sexual partner was significantly associated with condom use in extramarital sex. Respondents who were able to discuss condom use with their sexual partners were over eight times more likely to use condoms in extramarital sex than their counterparts who were not able to do so (confidence interval 5.190-14.021, OR $8.53, P<0.0001)$.

\section{Discussion}

This paper deals with a critical topic in behavioral research on HIV and AIDS in Nigeria, where a recent study has shown that over $30 \%$ of all new infections among males are from the general population in stable relationships, not in the traditional most-at-risk populations. ${ }^{34}$ A study in Nigeria has shown that although both polygynous and monogamous men are at risk of extramarital sex, men with three or more wives are more likely to have extramarital sex. ${ }^{8}$ This implies that nonuse of condoms by men exposes not only themselves but several other married women to the risk of HIV. The fact that only $46.3 \%$ of married men who engaged in extramarital 


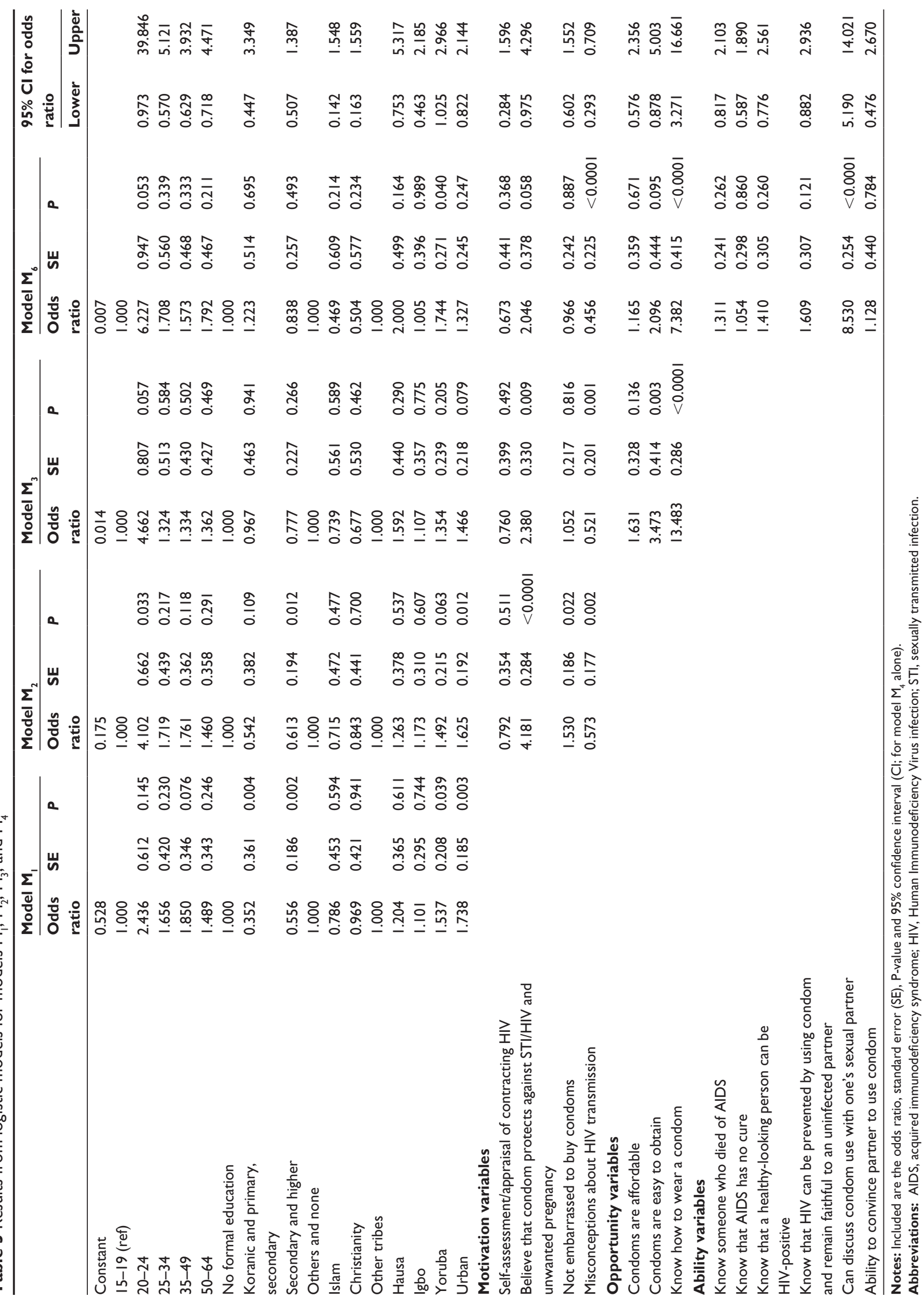


sex used condoms together with the high prevalence of polygyny exacerbates the risk of HIV infection in Nigeria for women within marriage. National surveys report that $33 \%$ of all married women are in polygynous unions, and $20 \%$ of married men report having two or more wives. ${ }^{35}$ Polygyny is not only common in northern Nigeria, where over $40 \%$ of women have cowives, but also in the southwest, where over $25 \%$ of married women share their husbands with other wives. ${ }^{35}$

Among the Yoruba, who inhabit most of southwestern Nigeria, wives commonly come to accept that their husbands will engage in extramarital sex, particularly during the postpartum period. ${ }^{8}$ Thus, while it is normative for a Yoruba woman to remain faithful, the same cannot be said of her husband. ${ }^{36}$ A study in Nigeria has shown that extramarital relationships are often open affairs. Thirty-five percent of married men mentioned that their wives knew of their extramarital affairs, while $65 \%$ said their relatives were aware. ${ }^{7}$ Thus, the acquisition of a second or third wife may be preceded by open-secret extramarital sexual liaisons. For men who engage in extramarital sex, the promotion of condom use should therefore be a major preventive strategy. ${ }^{37}$ Furthermore, Hatcher and Hughes ${ }^{38}$ reported in a study of heterosexual discordant couples that condom use was the best defense against seroconversion.

Multiple sexual partnering has been established to increase the risk of contracting HIV. In Nigeria, as in many other countries where HIV is transmitted mostly through heterosexual activities, the risk of transmission of HIV is largely determined by sex outside stable relationships, which may either be premarital or extramarital. ${ }^{39}$ Findings from studies in sub-Saharan Africa have also emphasized the importance of condom use in both marital and extramarital relationships. ${ }^{40}$ In a truly patriarchal society like Nigeria, a married woman whose husband engages in extramarital sex is at an elevated risk of HIV infection. Therefore, there is the need for programmers to understand the level and dynamics of condom use in extramarital relationships to assist them to design and implement appropriate interventions. Despite the common and risky nature of extramarital sex, only a few studies have reported on condom use in extramarital relationships.

In the multiple logistic regression models, age of respondents was categorized into 15-19 years (reference category), 20-24 years, 25-34 years, 35-49 years, and 50-64 years. The odds of using condoms in extramarital sex declined with increase in age-group (though not significantly). A similar finding among married men has been reported in Zimbabwe. ${ }^{40}$ Programmatically, it becomes imperative to address issues of cross-generational sex, as the older respondents who do not use condoms in their last extramarital sex act and yet have multiple extramarital partners constitute a risk to their spouses or cohabiting partners Similarly, place of residence was positively associated with condom use in last extramarital sex. Respondents who were resided in urban localities were more likely to use condoms in their last nonmarital sex compared with their counterparts residing in rural localities. Again, these findings underscore the need to strengthen prevention efforts in rural communities. In addition to the demographic characteristics that were controlled for in model $\mathrm{M}_{1}$, inclusion of the motivation indicators of the MOA conceptual framework shows that knowing that someone has died of AIDS and that AIDS does not have a cure are not significantly associated with condom use in extramarital sex.

After controlling for misconceptions, as shown in $\mathrm{M}_{6}$, none of the HIV knowledge variables was associated with condom use, eg, knowledge that using condoms and remaining faithful with one uninfected partner was not associated with condom use in extramarital sex. Our findings are, however, in contrast with Isiugo-Abanihe, ${ }^{13}$ whose study of five Nigerian towns found a positive relationship between knowledge and condom use in extramarital sex. This may be related to differences in samples reflecting the heterogeneity of Nigeria. ${ }^{8}$ Whereas our study is based on a nationally representative sample of men, Isiugo-Abanihe's study $^{13}$ was limited to five towns. Since both our study and Mitsunaga et $\mathrm{al}^{8}$ are based on nationally representative samples, the findings underscore the common gap between HIV knowledge and behavior. HIV research has shown that knowledge about HIV risk does not usually translate to changes in risky behavior. There is often a striking disparity between what individuals intellectually know about risk and how they actually behave. ${ }^{41}$

Since the objective of HIV prevention in Nigeria, as elsewhere, is behavior change, it is critical that HIVprevention efforts now advance beyond dissemination of basic factual messages about HIV and AIDS and begin to address other factors that influence why and how men who engage in extramarital sex behave with respect to HIV risk. Further studies are needed to explore the HIV risk-taking behaviors of men who engage in extramarital sex, particularly in rural areas. Is it that for some men, engaging in extramarital sex is a prelude to taking another wife? For these men, because pregnancy may be a welcome consequence, the use of condoms in such relationships becomes problematic. This can be understood within the context of $33 \%$ of married 
women in Nigeria living in polygynous homes. ${ }^{35}$ The role of infertility could also be explored. While primary infertility is low - about $3 \% \%^{35}$ - many Nigerian couples report problems of infertility. Community-based data suggest that up to $30 \%$ of couples in some parts of Nigeria have difficulties in achieving a desired conception after 2 years of marriage without the use of contraceptives. ${ }^{42}$ Nigerian gynecologists frequently report that infertility cases constitute between $60 \%$ and $70 \%$ of their consultations in tertiary health institutions. ${ }^{43,44}$ In addition, a recent population-based survey of women of reproductive age in Ile-Ife, Nigeria revealed that up to $20 \%$ of women have secondary infertility. ${ }^{45}$ Men often wrongly put the blame on women and present this as justification for extramarital affairs, which may result in marrying an additional wife. Orubuloye et $\mathrm{al}^{10}$ report that some married men engage in extramarital sex primarily for enjoyment. This to some men includes sex without condoms. Another study in Lagos observed that husbands go out "looking for younger partners as the glamour of initial (marital) relationship wanes." ${ }^{\prime 46}$

In the full model $\mathrm{M}_{6}$, only being a Yoruba, misconception about HIV transmission, knowledge about how to wear condoms, and discussion of condom use with partners were significantly associated with condom use in extramarital sex.

These findings have implications for HIV programming in Nigeria. For people to practice a promoted behavior, it is expected that they are provided with the opportunity that will enable them change behavior. Therefore, the opportunity variables show that individuals who believe that condoms are easy to obtain and affordable are more likely to use condoms in extramarital sex compared to those who do not believe same. As shown in this study, individuals who believe that condoms are easy to obtain and affordable are more likely to use condoms. HIV programmers should design intervention strategies to ensure availability. Perhaps condoms are now so cheap that affordability is not an important determinant for condom use. There is a need for further research to explore whether men who engage in extramarital sex do get condoms when and where they need them most. Furthermore, programmers need to ensure that people are given the skills to negotiate condom use and use condoms properly. Behavior-change communication efforts should provide integrated messages that include all three indices found to impact positively on condom use. Having misconceptions about modes of transmission is negatively and significantly associated with condom use in extramarital sex.

Self-efficacy about one's ability to wear condoms was significantly associated with condom use in extramarital sex. This finding is of particular importance. As noted, ${ }^{41}$ implementing HIV risk-reduction behavior change requires more than knowledge. Behavioral skills in condom use are critical. Asking men to use condoms will have relatively little impact unless they know how to use them correctly. Programmers need to know that to the extent that skills in the use of condoms are deficient, men will be poorly equipped to achieve success in condom use.

\section{Limitations of study}

As in most other behavioral and cross-sectional surveys, these data are based on self-reported sexual practices, and may suffer from the problem of underreporting of risk behaviors among the respondents, especially on the issue of extramarital sex. For instance, the reliability of self-reported answers to sensitive questions on sexual practices could have affected the results presented in this study. It is also important to note that the date are derived from cross-sectional surveys, which limits our conclusions on condom use and key motivation, ability, and opportunity factors, particularly in terms of timing and direction of relationships.

\section{Conclusion}

This paper focused on the adoption of safer sexual practices by exploring dynamics and levels of condom use in extramarital sex. Condom use in extramarital sex is a critical factor in the spread of STIs and HIV. However, very few HIV interventions in Nigeria and Africa in general are theory-driven. This paper has demonstrated the feasibility of applying the MOA theoretical framework in identifying some determinants of condom use by men in extramarital relationships. The study found that respondents who knew that HIV had no cure were more likely to use condoms. In terms of demographic background, men who were of the Yoruba tribe were more likely to use condoms compared with other tribes. Also, residing in urban areas was significantly associated with condom use. However, there was no significant association between education and condom use. It was found that men who knew how to wear condoms were thirteen times more likely to use a condom than their counterparts who did not know how to do so (OR 13.483, $P<0.0001$ ). Also, respondents who were able to discuss condom use with their sexual partners were over eight times more likely to use condoms in extramarital sex than their counterparts who could not discuss condom use with their sexual partners (OR 8.53, confidence interval 5.190-14.021, $P<0.0001)$. Affordability does not seem to be an explanatory factor; it is rather availability of condoms that impacts on condom use in extramarital sex. 
Furthermore, the odds of using condoms in extramarital sex decline with increasing age. This suggests a risk for younger women who normally engage in sexual relations with older men. Thus, while many condom programs target young persons, the needs of older married men should also be a focus for programs. Intervention efforts should therefore be intensified about improving skills, making condoms available, and providing men with the skills on how to wear condoms correctly.

\section{Acknowledgments}

The authors would like to thank the Federal Ministry of Health of Nigeria for granting them the permission to use the 2003, 2005, and 2007 NARHS datasets. The grants from the British Department for International Development (DFID) and United States Department for International Development (USAID) to implement these surveys are gratefully acknowledged.

\section{Disclosure}

The authors report no conflicts of interest in this work.

\section{References}

1. UNAIDS. AIDS epidemic update (global summary of the AIDS epidemic). 2005. Available from: www.unaids.org/en/media/unaids/contentassets/ dtatimport/publications/irc-pub06/epi_update2005_en.pdf. Accessed October 12, 2012.

2. Federal Ministry of Health. The 2005 National HIV/Syphilis Seroprevalence Sentinel Survey among Pregnant Women Attending Antenatal Clinics in Nigeria. Abuja, Nigeria: Federal Ministry of Health; 2006.

3. Federal Ministry of Health. National HIV/AIDS and Reproductive Health Survey (NARHS), 2007. Abuja, Nigeria: Federal Ministry of Health; 2009.

4. Federal Ministry of Health. HIV/STI Integrated Biological and Behavioural Surveillance Survey (IBBSS). Abuja, Nigeria: Federal Ministry of Health; 2008.

5. Adair T. Men's condom use in higher-risk sex: trends and determinants in five sub-Saharan countries. Demographic and Health Survey Working Paper. 2008;34.

6. Aniebue PN, Aniebue UU. HIV/AIDS-related knowledge, sexual practices and predictors of condom use among long-distance truck drivers in Nigeria. South Afr J HIV Med. 2009;10:54-56.

7. Akinnawo EO. Sexual networking, STDs and HIV/AIDS transmission among police officers. Health Transit Rev. 1995;5 Suppl:113-121

8. Mitsunaga TM, Powell AM, Heard NJ. Extramarital sex among Nigerian men: polygyny and other factors. J Acquir Immune Defic Syndr. 2005;39:478-488.

9. Orubuloye IO, Caldwell JC, Caldwell P. Sexual networking and the risk of AIDS in Southwest Nigeria. In: Dyson T, editor. Sexual Behaviour and Networking: Anthropological and Socio-cultural Studies on the Transmission of HIV. Liège, Belgium: Ordina Editions; 1990:283-302.

10. Orubuloye IO, Caldwell P, Caldwell JC. The role of high-risk occupations in the spread of AIDS: truck drivers and itinerant market women in Nigeria. Int Fam Plan Perspect. 1992;19:43-48.

11. Caldwell JC, Orubuloye IO, Caldwell P. The destabilization of the traditional Yoruba system. Popul Dev Rev. 1991;17:229-262.

12. Smith SD. Promiscuous girls, good wives and cheating husbands: gender inequality, transitions to marriage, and infidelity in southeastern Nigeria. Anthropol Q. 2010;83:123-152.
13. Isiugo-Abanihe UC. Extramarital relations and perceptions of HIV/ AIDS in Nigeria. Health Transit Rev. 1994;4:111-125.

14. World Bank. Confronting AIDS: Public Priorities in a Global Epidemic. New York: Oxford University Press; 1997.

15. Oyediran K, Isiugo-Abanihe UC, Feyisetan BJ, Ishola GP. Prevalence of and factors associated with extramarital sex among Nigerian men. Am J Mens Health. 2010;4:124-134.

16. Cleland JG, Ali MM, Capo-Chichi V. Post-partum sexual abstinence in West Africa: implications for AIDS control and family planning programmes. AIDS. 1999;13:125-131.

17. Glynn JR, Caraël M, Buvé A, Musonda RM, Kahindo M. HIV risk in relation to marriage in areas with high prevalence of HIV infection. J Acquir Immune Defic Syndr. 2003;33:526-535.

18. Rothschild M. Carrots, sticks and promises: a conceptual framework for the management of public health and social issue behaviours. J Mark. 1999;63:24-37.

19. Anderson RM. Revisiting the behavioral model and access to health care: does it matter? J Health Soc Behav. 1995;36:1-10.

20. MacInnis DJ, Moorman C, Jaworski BJ. Enhancing and measuring consumer's motivation, opportunity, and ability to process brand information from ads. J Mark. 1991;55:32-53.

21. Binney W, Hall J, Shaw M. A new social marketing model: testing and application of the MOA framework. 2004. Available from: http:// anzmac.info/conference/2001/anzmac/AUTHORS/pdfs/Binney.pdf. Accessed April 11, 2013.

22. Hallahan K. Enhancing motivation, ability and opportunity to process public relations messages. Public Relat Rev. 2000;26:463-480.

23. Moorman C, Matulich E. A model of consumers' preventive health behaviours: the role of health motivation and health ability. J Consum Res. 1993;20:209-228.

24. Wiggins J. Motivation, ability and opportunity to participate: a re-conceptualization of the RAND model of audience development. Int J Arts Manag. 2004;7:22-33.

25. Chapman S. Evaluating social marketing interventions. In: Thorogood M, Coombes Y, editors. Evaluating Health Promotion. Oxford: Oxford University Press; 2004.

26. Population Services International. PSI Behavior Change Framework: "Bubbles" - Proposed Revision. Washington: PSI Research Division; 2004. Available from: http://www.psilearning.com/USF_Data/web/ lesson2/BC_Framework.pdf. Accessed April 11, 2013.

27. Kassegne S, Kays MB, Nzohabonayo J. Evaluation of a social marketing intervention promoting oral rehydration salts in Burundi. BMC Public Health. 2011;11:115.

28. Longfield K, Panyanouvong X, Chen J, Kays B. Increasing safer sexual behaviour among Lao kathoy through an integrated social marketing approach. BMC Public Health. 2011;11:872.

29. Siemsen E, Roth AV, Balasubramanian S. How motivation, opportunity, and ability drive knowledge-sharing: the constraining-factor model. J Oper Manag. 2008;26:426-445.

30. Federal Ministry of Health. National HIV/AIDS and Reproductive Health Survey (NARHS). Abuja, Nigeria: Federal Ministry of Health; 2003.

31. Federal Ministry of Health. National HIV/AIDS and Reproductive Health Survey (NARHS). Abuja, Nigeria: Federal Ministry of Health; 2006.

32. Agresti A. Categorical Data Analysis, 2nd ed. New York: Wiley; 2002.

33. Collett D. Modelling Binary Data. London: Chapman \& Hall; 2003.

34. National Agency for the Control of AIDS. Modes of HIV Transmission in Nigeria: Analysis of the Distribution of New HIV Infections in Nigeria and Recommendations for Prevention. Abuja, Nigeria: National Agency for the Control of AIDS; 2009.

35. National Population Commission, ICF Macro. Nigeria Demographic and Health Survey (NDHS) Nigeria. Abuja, Nigeria: National Population Commission and ICF Macro; 2009.

36. Ajala AS. HIV/AIDS in Yoruba perspective: a conceptual discourse. J Soc Sci. 2007;14:235-241.

37. Adetunji J, Meekers D. Consistency in condom use in the context of HIV/AIDS in Zimbabwe. J Biosoc Sci. 2001;33:121-138. 
38. Hatcher RA, Hughes MS. The truth about condoms. SIECUS Rep. 1988;17:1-8

39. Ahlburg DA, Jensen ER, Perez AE. Determinants of extramarital sex in the Philippines. Health Transit Rev. 1997;7 Suppl:467-479.

40. Adetunji J. Condom use in marital and nonmarital relationships in Zimbabwe. Int Fam Plan Perspect. 2000;26:196-200.

41. Kelley JA. Changing HIV Risk Behaviour: Practical Strategies. New York: Guilford Press; 1995.

42. Adetoro OO, Ebomoyi EW. The prevalence of infertility in a rural Nigerian community. Afr J Med Sci. 1991;20:23-27.

43. Megafu U. Surgical causes and management of infertility in Nigeria. Int Surg. 1988;73:144-148.
44. Otubu JA, Olarewaju RS. Hysteroscopy in infertile Nigerian women. Afr J Med Med Sc. 1989;18:117-121.

45. Snow RC, Okonofua FE, Kane T, Farley TMM, Pinol A. Prevalence and determinants of infertility in Ile-Ife, Nigeria. Contracept Fertil Sex. 1995;23 Suppl 1:544.

46. Adegbola O, Babatola O. Premarital and extra-marital sex in Lagos, Nigeria. In: Caldwell JC, Orubuloye IO, Ntozi JPM. The Continuing African AIDS Epidemic. Canberra: Health Transition Centre, National Centre for Epidemiology and Population Health, Australian National University; 1999:19-44.
HIV/AIDS - Research and Palliative Care

\section{Publish your work in this journal}

HIV/AIDS - Research and Palliative Care is an international, peerreviewed open-access journal focusing on advances in research in HIV, its clinical progression and management options including antiviral treatment, palliative care and public healthcare policies to contro viral spread. The journal welcomes original research, basic science,

\section{Dovepress}

clinical \& epidemiological studies, reviews \& evaluations, expert opinion \& commentary, case reports \& extended reports. The manuscript management system is completely online and includes a very quick and fair peer-review system. Visit http://www.dovepress.com/ testimonials.php to read real quotes from published authors.

\footnotetext{
Submit your manuscript here: http://www.dovepress.com/hivaids---research-and-palliative-care-journal
} 